\title{
Evaluation of Odd-Even Vehicle Registration Number Regulation Before and After Expansion of the Rule in Jakarta
}

\author{
Ferhat Januar Rediat Supriana \\ Civil Engineering Department \\ Indonesia University \\ Depok, Indonesia \\ ferhat.supriana@gmail.com \\ Martha Leni Siregar \\ Civil Engineering Department \\ Indonesia University \\ Depok, Indonesia \\ leni@eng.ui.ac.id
}

\author{
Ellen Sophie Wulan Tangkudung \\ Civil Engineering Department \\ Indonesia University \\ Depok, Indonesia \\ ellen@eng.ui.ac.id \\ Andyka Kusuma \\ Civil Engineering Department \\ Indonesia University \\ Depok, Indonesia \\ andyka.k@eng.ui.ac.id
}

\begin{abstract}
The Odd-Even Number Policy intended to limit the DKI Jakarta Provincial Government has implemented vehicle traffic. Since its first implementation in 2016, this policy has undergone several changes, such as the number of roads and active duration. The purpose of this study is to analyze and evaluate two traffic data and periods of policy enactment. The method used in this study is a descriptive statistical analysis and correlation test of each traffic variable with odd-even policy period variables using secondary data obtained from relevant agencies. The results show that each variable has different relationships with odd-even policy periods, which means that odd-even policies affect some of the traffic variables. As a result, there is a $42.97 \%$ decrease in the number of average travel time from Period I to Period IV of the implementation, a $76.36 \%$ increase in the number of average speed from Period I to Period IV, a $21.35 \%$ decrease in the number of average vehicle volume from Period II to Period III, and a $6.67 \%$ increase in the average number of BRT passengers from Period I to Period IV.
\end{abstract}

Keywords: traffic restrictions, odd-even, policy periods, comparisons between periods

\section{INTRODUCTION}

The odd-even number policy is a regulation that restricts access to certain areas to vehicles whose license plate numbers correspond to the date of the current day. This regulation was made official by the governor of DKI Jakarta, Basuki Tjahaja Purnama, in June 2016. This regulation replaces the 3-in-1 regulation.

This regulation was initially applied to the same streets that applied the 3-in-1 regulation, which are Sisingamangaraja St., Jenderal Sudirman St., M.H. Thamrin St., Medan Merdeka Barat St. and a section of Jenderal Gatot Subroto St., between the Jenderal Gatot Subroto St. Gerbang Pemuda St. intersection and the H.R. Rasuna Said St. - Jenderal Gatot Subroto St. intersection, with active durations 07:00-10:00 and 16:00-19:00 on weekdays. As time goes by, the coverage area of this regulation has expanded into a total of $44 \mathrm{~km}$ from October $13^{\text {th }}, 2018$ to

This study is funded through the PITTA grant scheme No. ND162/UN2.R3.1/PPM.00/2019
December $31^{\text {st }}, 2018$.

A comparative study needs to be done to evaluate the significance of the expansion, where the results of the study can be used for the making of future regulations. This research aims to analyze and evaluate traffic data of the two periods of regulation application.

\section{THEORETICAL BACKGROUND}

\section{A. Transportation Demand Management (TDM) and the} Odd-Even Vehicle Restriction Regulation

Transportation Demand Management (TDM) is a method to change travel behaviour, in aims of avoiding the expansion of existing transportation systems due to the occurrence of transportation-related issues [1]. In Jakarta, the increase of private vehicle usage is due to several factors such as the increase of downtown area land prices resulting in the dispersion of settlements to suburban areas, lack of transport modes coverage, and the lack of punctuality served by public transports [2]. The TDM strategy has been implemented in Jakarta to resolve these issues from several sectors, such as the odd-even regulation from the regulation sector.

The odd-even regulation is an implementation of the TDM strategy to solve transportation-related problems such as traffic jams and air pollution. This system has also been implemented in other countries such as India, since 2016 in New Delhi [3] and Beijing, China, in 2008, when the Olympic Games were held [4].

\section{B. The Odd-Even Vehicle Restriction Regulation in Jakarta}

Article 93 paragraph (1) of the 2009 Constitution no. 22: "Traffic Management and Engineering is carried out to optimize the use of the road network and traffic movement in order to guarantee the Security, Safety, Order and Smoothness of Road Traffic and Transportation", paragraph (2) letter g: "control of Traffic on the Road; and / or.", paragraph (3) letter a: "planning" and letter b: "arrangement", Article 133 paragraph (1): "To improve the efficiency and 
Article 133 paragraph (1): "To improve the efficiency and effectiveness of the use of Traffic Space and control the Traffic movement, traffic management needs to be carried out..." and paragraph (2) letter b which contains "Traffic restrictions on individual corridors or certain areas at certain times and roads;" explains that a policy which was an implementation of the Transport Demand Management was needed to regulate traffic in Jakarta. This regulation is also related to Article 78 paragraph (2) letter $n$ of Regional Regulation Number 5 the Year 2014 concerning Transportation, which is regulated regarding the control of traffic on roads.

The basis of the law and the regulation is stated in the 2016 Governor Regulation number 164 concerning Traffic Restrictions with Odd-Even License Plate System. This regulation states that all four-wheeled vehicle with oddnumbered license plates is forbidden from accessing several streets during even-numbered dates and vice versa. Following article 3 of the regulation, this system is active on Monday through Friday at 07:00-10:00 and 16:00-20:00.

\section{Traffic Data Variables}

There are several variables used in this research to describe traffic behaviour. These variables include basic and derivative variables. The basic variables are Flow $(q)$, Density $(k)$ and Speed $(u)$. The derivative variables are Headway $(h)$ and Spacing $(s)$. All parameters can define the time needed to cover a section of a road, commonly referred to as travel time [5].

\section{Level of Service}

The capacity of a traffic network is the maximum number of vehicles that can pass a particular road in a onehour duration without generating traffic congestions that can lead to time constraints, danger, or the reduction of drivers' freedom in driving with ease. The level of service (LOS) is often used as a measurement of the factors affecting the increase in traffic volume. Every road can be categorized into different levels of service between $\mathrm{A}$ to $\mathrm{F}$ with $\mathrm{A}$ being the best and $\mathrm{F}$ being the worst [6]. The level of service is used to quantify the quality of a road section, described with the ratio between volume and capacity $(V / C)$. This ratio needs to be lower than 1 to give excellent road quality.

\section{E. Correlation Test}

Correlation Test is a test to find out the correlation between variables. The correlation between variables is commonly described with the Pearson Correlation coefficient, a coefficient with values ranging between -1 and 1. Values closer to 1 show positive correlation while vales are closer to -1 show negative correlation [7]. The positive correlation is when the variables are directly proportional while negative correlation is when the variables are inversely proportional to each other. A correlation coefficient valued 0 means that the variables show no correlation whatsoever [8].

The calculation of significance affects the methods Hypothesis Zero $(\mathrm{HO})$ and Working Hypothesis (HI).
Hypothesis Zero is a hypothesis that states no correlation between the independent (X) and the dependent (Y) variable, where the $\mathrm{X}$ variable will be tested for its effects on the Y variable. Working Hypothesis is a hypothesis that states that there is a correlation between the $\mathrm{X}$ variable and the $\mathrm{Y}$ variable. The results of $H 1$ calculations will be used as the basis of data calculations of this research.

\section{RESEARCH METHODOLOGY}

In this research, the secondary data used are the flow, speed and travel time during Period I and Period V of the implementation of the odd-even regulation, which shows the effect of the expansion of the regulation, and the TransJakarta passenger data before and after the expansion, which shows the effect of the expansion towards public transportations. This research focuses on TransJakarta as the representation of the several existing public transportations.

The issue reviewed in this research, for several variables of the research, is the implementation of the odd-even regulation in Period I (the first coverage area of the regulation) and Period IV (after the expansion). The expansion was initially implemented to support the execution of the 2018 Asian Games and Asian Para games. With the success of the implementation in Period II (during the 2018 Asian Games) and Period III (during the 2018 Asian Para games), the implementation period has been extended until December 31 ${ }^{\text {st }}$, 2018 though with reduced active duration. However, the areas where this regulation was implemented did not show any significant changes, thus resulting in a hypothesis that there is no difference in the traffic condition between Period I and Period IV. The other issue discussed in this research that involved other variables is the implementation of the regulation during Period II and Period III.

From the many areas where this regulation is implemented as stated in the 2018 Governor Regulation number 106, only a few will be selected to be studied in this research. The H.R. Rasuna Said St. and Jenderal Sudirman St. will be studied for the speed and travel time variables while the Jenderal Sudirman St. and M.T. Haryono St. will be studied for the volume variable.

In this hypothesis, the visible difference between the variables can be assumed as the presence of a data shift due to the assumed causal variable, namely the implementation of the odd-even regulation. To identify the significance of each variable, all the variables will be processed using the Pearson Product-Moment Correlation Coefficient method from which a Pearson Coefficient $(\rho)$ will be obtained. In addition to this, significance calculation results can also be used to identify the correlation between variables.

\section{Research Methodology}

\section{A. Travel Time}

In this variable, the data being compared are the travel time data between $26^{\text {th }}$ and $29^{\text {th }}$ of June 2018, when the regulation coverage area has not been expanded, and the travel time data between $12^{\text {th }}$ and $15^{\text {th }}$ of November 2018 , 
when the expansion has been implemented. The data processing results in an average travel time of the four road segments, as shown below, both with the data before and after the expansion. The results are shown below.

TABle I. Average Travel Time Before and After The Regulation Coverage Area Expansion

\begin{tabular}{|c|c|c|c|c|c|c|}
\hline Segments & Time & $\begin{array}{c}\text { Before } \\
\text { Expansion } \\
\text { (min) }\end{array}$ & $\begin{array}{c}\text { After } \\
\text { Expansion } \\
\text { (min) }\end{array}$ & $\begin{array}{c}\text { Difference } \\
\text { (minute) }\end{array}$ & Percentage & $\begin{array}{c}\text { Average } \\
\text { Percentage }\end{array}$ \\
\hline \multicolumn{7}{|l|}{ Segment 1} \\
\hline \multirow{2}{*}{ Sudirman - Merdeka Barat } & Morning & 22.57 & 13.14 & 9.43 & 41.78 & \multirow{2}{*}{42.07} \\
\hline & Afternoon & 24.79 & 14.29 & 10.50 & 42.36 & \\
\hline \multirow{2}{*}{ Merdeka Barat - Sudirman } & Morning & 25.50 & 14.14 & 11.36 & 44.55 & \multirow{2}{*}{44.26} \\
\hline & Afternoon & 33.14 & 18.57 & 14.57 & 43.96 & \\
\hline \multicolumn{7}{|l|}{ Segment 2} \\
\hline \multirow{2}{*}{ Kuningan - Menteng } & Morning & 10.43 & 6.22 & 4.22 & 40.41 & \multirow{2}{*}{41.29} \\
\hline & Afternoon & 11.36 & 6.57 & 4.79 & 42.17 & \\
\hline \multirow{2}{*}{ Menteng - Kuningan } & Morning & 11.50 & 6.64 & 4.86 & 42.26 & \multirow{2}{*}{44.23} \\
\hline & Afternoon & 14.07 & 7.57 & 6.50 & 46.20 & \\
\hline
\end{tabular}

TABLE I shows that the decrease in travel time of the same road segments can be seen. Segment 1 experiences a travel time decrease of $43.17 \%$ while Segment 2 experiences a $42.76 \%$ decrease in travel time. In average, the expansion of the regulation coverage area causes a $42.97 \%$ decrease in travel time.

TABLE II. CORRELATION OF TRAVEL TIME AND RELATED VARIABLES IN SEGMENT 1

\begin{tabular}{|l|l|l|l|l|}
\hline \multirow{4}{*}{ Variable } & \multicolumn{4}{|c|}{ Correlation } \\
\cline { 2 - 5 } & \multicolumn{2}{|c|}{$\begin{array}{c}\text { Sudirman - Merdeka } \\
\text { Barat }\end{array}$} & \multicolumn{2}{c|}{$\begin{array}{c}\text { Merdeka Barat - } \\
\text { Sudirman }\end{array}$} \\
\cline { 2 - 5 } & $\begin{array}{c}\text { Pearson } \\
\text { Correlation }\end{array}$ & $\begin{array}{c}\text { Sig. (2- } \\
\text { tailed) }\end{array}$ & $\begin{array}{c}\text { Pearson } \\
\text { Correlation }\end{array}$ & $\begin{array}{c}\text { Sig. (2- } \\
\text { tailed) }\end{array}$ \\
\hline Date & -0.78 & 0.00 & -0.72 & 0.00 \\
\hline Time & 0.14 & 0.32 & 0.35 & 0.01 \\
\hline $\begin{array}{l}\text { Odd-Even } \\
\text { Period }\end{array}$ & -0.90 & 0.00 & -0.81 & 0.00 \\
\hline
\end{tabular}

TABLE III. CORRELATION OF TRAVEL TIME AND RELATED VARIABLES IN SEGMENT 2

\begin{tabular}{|c|c|c|c|c|}
\hline \multirow{3}{*}{ Variable } & \multicolumn{4}{|c|}{ Correlation } \\
\hline & \multicolumn{2}{|c|}{$\begin{array}{c}\text { Sudirman - Merdeka } \\
\text { Barat }\end{array}$} & \multicolumn{2}{|c|}{$\begin{array}{c}\text { Merdeka Barat - } \\
\text { Sudirman }\end{array}$} \\
\hline & $\begin{array}{c}\text { Pearson } \\
\text { Correlation }\end{array}$ & $\begin{array}{l}\text { Sig. (2- } \\
\text { tailed) }\end{array}$ & $\begin{array}{c}\text { Pearson } \\
\text { Correlation }\end{array}$ & $\begin{array}{l}\text { Sig. (2- } \\
\text { tailed) }\end{array}$ \\
\hline Date & -0.81 & 0.00 & -0.81 & 0.00 \\
\hline Time & 0.13 & 0.35 & 0.25 & 0.05 \\
\hline $\begin{array}{l}\text { Odd-Even } \\
\text { Period }\end{array}$ & -0.92 & 0.00 & -0.87 & 0.00 \\
\hline
\end{tabular}

TABLE IV.

Average Speed Before and After the Regulation Coverage Area Expansion

\begin{tabular}{|c|c|c|c|c|c|c|}
\hline Segments & Time & $\begin{array}{c}\text { Before } \\
\text { Expansion } \\
(\mathrm{min})\end{array}$ & $\begin{array}{c}\text { After } \\
\text { Expansion } \\
\text { (min) }\end{array}$ & $\begin{array}{c}\text { Difference } \\
\text { (minute) }\end{array}$ & Percentage & $\begin{array}{c}\text { Average } \\
\text { Percentage }\end{array}$ \\
\hline \multicolumn{7}{|l|}{ Segment 1} \\
\hline \multirow{2}{*}{ Sudirman - Merdeka Barat } & Morning & 21.78 & 37.34 & 15.56 & 71.42 & \multirow{2}{*}{77.37} \\
\hline & Afternoon & 17.80 & 32.63 & 14.83 & 83.31 & \\
\hline \multirow{2}{*}{ Merdeka Barat - Sudirman } & Morning & 18.24 & 33.24 & 15.00 & 82.26 & \multirow{2}{*}{81.84} \\
\hline & Afternoon & 14.05 & 25.48 & 11.44 & 81.42 & \\
\hline \multicolumn{7}{|l|}{ Segment 2} \\
\hline \multirow{2}{*}{ Kuningan - Menteng } & Morning & 24.01 & 39.75 & 15.74 & 65.57 & \multirow{2}{*}{68.82} \\
\hline & Afternoon & 21.88 & 37.65 & 15.77 & 72.07 & \\
\hline \multirow{2}{*}{ Menteng - Kuningan } & Morning & 21.78 & 37.34 & $15 . .56$ & 71.42 & \multirow{2}{*}{77.37} \\
\hline & Afternoon & 17.80 & 32.63 & 14.83 & 83.31 & \\
\hline
\end{tabular}

TABLE II and TABLE III show the results of the processing of the data in SPSS to identify the correlation between the odd-even period variable to the travel time variable. The Pearson Coefficients for Segment 1 are -0.90 and -0.81 while for Segment 2, the coefficients are -0.92 and -0.87 . These tables show that the travel time variable is inversely proportional to the odd-even period, meaning that with increasing regulation coverage area, the travel time in the road segments will decrease.

\section{B. Speed}

The speed data obtained were processed precisely the same way as the travel time data. This because this data is processed for the same purpose that the previous data had, which is to identify the effects the odd-even period have towards the speed in the road segments reviewed. The results of the data processing are as follows on TABLE IV. 
From the data above, the increase of speed in the road segments can be seen. Segment 1 experiences a speed increase of $79.61 \%$ while Segment 2 experiences a $73.10 \%$ speed increase. In average, the expansion of the regulation coverage area causes a $76.36 \%$ increase in speed.

TABLE V. CORRElation of SPEed AND Related VARIABles IN SEGMENT 1

\begin{tabular}{|c|c|c|c|c|}
\hline \multirow{3}{*}{ Variable } & \multicolumn{4}{|c|}{ Correlation } \\
\hline & \multicolumn{2}{|c|}{$\begin{array}{c}\text { Sudirman - Merdeka } \\
\text { Barat }\end{array}$} & \multicolumn{2}{|c|}{$\begin{array}{c}\text { Merdeka Barat - } \\
\text { Sudirman }\end{array}$} \\
\hline & $\begin{array}{c}\text { Pearson } \\
\text { Correlation }\end{array}$ & $\begin{array}{l}\text { Sig. (2- } \\
\text { tailed) }\end{array}$ & $\begin{array}{c}\text { Pearson } \\
\text { Correlation }\end{array}$ & $\begin{array}{l}\text { Sig. (2- } \\
\text { tailed) }\end{array}$ \\
\hline Date & 0.74 & 0.00 & 0.67 & 0.00 \\
\hline Time & 0.88 & 0.00 & 0.78 & 0.00 \\
\hline $\begin{array}{l}\text { Odd-Even } \\
\text { Period }\end{array}$ & -0.14 & 0.30 & -0.34 & 0.01 \\
\hline
\end{tabular}

TABLE VI. CORRELATION BETWEEN SPEED AND RELATED VARIABLES IN SEGMENT 2

\begin{tabular}{|c|c|c|c|c|}
\hline \multirow{3}{*}{ Variable } & \multicolumn{4}{|c|}{ Correlation } \\
\hline & \multicolumn{2}{|c|}{$\begin{array}{c}\text { Sudirman - Merdeka } \\
\text { Barat }\end{array}$} & \multicolumn{2}{|c|}{$\begin{array}{c}\text { Merdeka Barat - } \\
\text { Sudirman }\end{array}$} \\
\hline & $\begin{array}{c}\text { Pearson } \\
\text { Correlation }\end{array}$ & $\begin{array}{l}\text { Sig. (2- } \\
\text { tailed) }\end{array}$ & $\begin{array}{c}\text { Pearson } \\
\text { Correlation }\end{array}$ & $\begin{array}{l}\text { Sig. (2- } \\
\text { tailed) }\end{array}$ \\
\hline Date & 0.82 & 0.00 & 0.83 & 0.00 \\
\hline Time & 0.94 & 0.00 & 0.91 & 0.00 \\
\hline $\begin{array}{l}\text { Odd-Even } \\
\text { Period }\end{array}$ & -0.13 & 0.36 & -0.27 & 0.05 \\
\hline
\end{tabular}

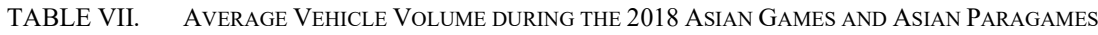

\begin{tabular}{|l|l|l|l|l|l|l|}
\hline \multicolumn{1}{|c|}{ Segments } & \multicolumn{1}{|c|}{ Time } & $\begin{array}{c}\text { Asian Games } \\
\text { (pcu/hr) }\end{array}$ & $\begin{array}{c}\text { Asian Paragames } \\
\text { (pcu/hr) }\end{array}$ & \multicolumn{1}{|c|}{$\begin{array}{c}\text { Difference } \\
\text { (minute) }\end{array}$} & \multicolumn{1}{|c|}{ Percentage } \\
Percentage
\end{tabular}

From the data above, the decrease in vehicle volume in the road segments can be seen. Segment 1 experiences a volume decrease of $7.95 \%$, while Segment 2 experiences a $35.10 \%$ volume decrease. In average, the expansion of the regulation coverage area causes a $21.53 \%$ decrease in vehicle volume.

TABLE VIII. CHARACTERISTICS OF THE REVIEWED ROAD SEGMENTS

\begin{tabular}{|l|l|l|l|l|l|l|}
\hline \multicolumn{1}{|c|}{ Segments } & $\begin{array}{c}\text { Type (1 } \\
\text { Direction) }\end{array}$ & $\begin{array}{c}\text { Effective Lane } \\
\text { Width (m) }\end{array}$ & Separator & Side Obstructions & Roadside Width (m) & Size (Mill) \\
\hline Segment 1 & 3 & 3 & - & VH & 1 \\
\hline Sudirman - (North-South) & 3 & 3 & - & VH & 1 \\
\hline Sudirman - (South-North) & 3 & 3 & - & VH & $>3$ \\
\hline Segment 2 & 3 & - & VH & 2 \\
\hline M.T. Haryono - (West-East) & 2 & 2 & $>3$ \\
\hline M.T. Haryono - (West-East) & 2 & & $>3$ \\
\hline
\end{tabular}

TABLE $\mathrm{V}$ and TABLE VI show the results of the processing of the data in SPSS to identify the correlation between the odd-even period variable to the speed variable. The Pearson Coefficients for Segment 1 are 0.88 and 0.78, while for Segment 2, the coefficients are 0.94 and 0.91 . This shows that the speed variable is directly proportional to the odd-even period, meaning that with increasing regulation coverage area, the speed in the road segments will increase.

\section{Vehicle Volume}

For the volume variable, the data compared are the volume data in the $20^{\text {th }}$ of August 2018, when the regulation area has not been expanded, and the in the $1^{\text {st }}$ of October 2018, when the expansion has been implemented.

This data was obtained from the Department of Transportation of DKI Jakarta. In the two road segments, a survey was done using the traffic counting method for 15 minutes of one hour in the morning and the afternoon. The morning survey is done between 5:00 and 8:00 WIB while the afternoon survey is done between 16:00 and 19:00 WIB. The data obtained is then processed in order to obtain their average values. The results are presented in the TABLE VII.
The data above were processed again to identify each segment's V/C ratio. The maximum number of vehicles in each road segment was then compared to the corresponding road segment's capacity. The results are shown below in TABLE VIII. 
TABLE IX. BASE CAPACITY AND FACTORED CAPACITY OF THE REVIEWED ROAD SEGMENTS

\begin{tabular}{|l|l|l|l|l|l|l|}
\hline \multicolumn{1}{|c|}{ Segments } & Time & Asian Games (pcu/hr) & $\begin{array}{c}\text { Asian Paragames } \\
\text { (pcu/hr) }\end{array}$ & $\begin{array}{c}\text { Difference } \\
\text { (minute) }\end{array}$ & Percentage & Average Percentage \\
\hline Segment 1 & \multicolumn{7}{|l|}{} \\
\hline Sudirman - (North-South) & 4950 & 0.92 & 1 & 0.88 & 1.04 & 4168 \\
\hline Sudirman - (South-North) & 4950 & 0.92 & 1 & 0.88 & 1.04 & 4168 \\
\hline Segment 2 & 1 & 0.96 & 1.04 & 3031 \\
\hline M.T. Haryono - (West-East) & 3300 & 0.92 & 1 & 0.96 & 1.04 & 3031 \\
\hline M.T. Haryono - (West-East) & 3300 & 0.92 & 1 & \\
\hline
\end{tabular}

table $X . \quad$ Degree of Saturation of the Reviewed Road Segments

\begin{tabular}{|l|l|l|l|l|l|}
\hline \multicolumn{1}{|c|}{ Segments } & \multicolumn{1}{|c|}{ Asian Games } & V/C Ratio & Asian Paragames & V/C Ratio \\
\hline Segment 1 & Morning & 2779 & 0.67 & 2066 & 0.50 \\
\hline \multirow{2}{*}{ Sudirman - (North-South) } & Afternoon & 3831 & 0.92 & 2848 & 0.68 \\
\hline \multirow{2}{*}{ Sudirman - (South-North) } & Morning & 4613 & 1.11 & 5063 & 1.21 \\
\cline { 2 - 6 } & Afternoon & 2538 & 0.61 & 2786 & 0.67 \\
\hline Segment 2 & Morning & 1588 & 0.52 & 1350 \\
\hline \multirow{2}{*}{ M.T. Haryono - (West-East) } & Afternoon & 3671 & 1.21 & 3120 & 0.45 \\
\hline \multirow{2}{*}{ M.T. Haryono - (West-East) } & Morning & 4765 & 1.57 & 2136 & 1.03 \\
\cline { 2 - 7 } & Afternoon & 517 & 1.16 & 1606 & 0.70 \\
\hline
\end{tabular}

TABLE XI. Degree of SATURATion of THE REviewed RoAd SEgments

\begin{tabular}{|c|c|c|c|c|c|c|c|c|}
\hline Segments & Time & $\begin{array}{c}\text { Before } \\
\text { Expansion }\end{array}$ & V/C Ratio & LOS & $\begin{array}{c}\text { After } \\
\text { Expansion }\end{array}$ & V/C Ratio & LOS & Difference \\
\hline \multicolumn{9}{|l|}{ Segment 1} \\
\hline \multirow{2}{*}{ Sudirman - (North-South) } & Morning & 2779 & 0.67 & $\mathrm{C}$ & 2066 & 0.50 & $\mathrm{C}$ & 0.17 \\
\hline & Afternoon & 3831 & 0.92 & $\mathrm{E}$ & 2848 & 0.68 & $\mathrm{C}$ & 0.24 \\
\hline \multirow{2}{*}{ Sudirman - (South-North) } & Morning & 4613 & 1.11 & $\mathrm{~F}$ & 5063 & 1.21 & $\mathrm{~F}$ & -0.11 \\
\hline & Afternoon & 2538 & 0.61 & $\mathrm{C}$ & 2786 & 0.67 & $\mathrm{C}$ & -0.06 \\
\hline \multicolumn{9}{|l|}{ Segment 2} \\
\hline \multirow{2}{*}{ M.T. Haryono - (West-East) } & Morning & 1588 & 0.52 & $\mathrm{C}$ & 1350 & 0.45 & $\mathrm{C}$ & 0.08 \\
\hline & Afternoon & 3671 & 1.21 & $\mathrm{~F}$ & 3120 & 1.03 & $\mathrm{~F}$ & 0.18 \\
\hline \multirow{2}{*}{ M.T. Haryono - (West-East) } & Morning & 4765 & 1.57 & $\mathrm{~F}$ & 2136 & 0.70 & $\mathrm{C}$ & 0.87 \\
\hline & Afternoon & 3517 & 1.16 & $\mathrm{~F}$ & 1606 & 0.53 & $\mathrm{C}$ & 0.63 \\
\hline
\end{tabular}

Based on the data shown above from TABLE IX, TABLE $\mathrm{X}$, and TABLE XI; V/C ratio was obtained for each segment and periods. The results show that there is a change of LOS in several of the road segments. The north-south segment of Jenderal Sudirman St. afternoon traffic changed from $\mathrm{E}$ to $\mathrm{C}$ and the east-west segment of M.T. Haryono St. morning and afternoon traffic changed from $\mathrm{F}$ to $\mathrm{C}$. Moreover, there is a noticeable difference between the $\mathrm{V} / \mathrm{C}$ ratio from before to after the expansion. The most significant difference can be seen in the east-west segment of the M.T. Haryono St. morning traffic with a V/C ratio difference of 0.87 while the smallest can be seen in the west-east segment M.T. Haryono morning traffic with a V/C ratio difference of 0.08 . It can also be seen from the table above that in the north-south segment of Jenderal Sudirman St., the V/C ratio increases by 0.11 in the morning and 0.06 in the afternoon, thus making no change in the segment's LOS.

TABLE XII and TABLE XIII show the results of the processing of the data in SPSS to identify the correlation between the odd-even period variable to the vehicle volume variable. The Pearson Coefficients for Segment 1 are -0.563 and -0.126 while for Segment 2, the coefficients are -0.211 and -0.802 . This result happens because the trip generation in the different road segments varies with different times of the day. It can be concluded that the odd-even period does not significantly affect vehicle volumes.

TABLE XII. CORRELATION OF Volume IN SEgment 1

\begin{tabular}{|l|l|l|l|l|}
\hline \multirow{4}{*}{ Variable } & \multicolumn{3}{|c|}{ Correlation } \\
\cline { 2 - 5 } & \multicolumn{2}{|c|}{$\begin{array}{c}\text { Sudirman-Merdeka } \\
\text { Barat }\end{array}$} & \multicolumn{2}{c|}{$\begin{array}{c}\text { Merdeka Barat - } \\
\text { Sudirman }\end{array}$} \\
\cline { 2 - 5 } & $\begin{array}{c}\text { Pearson } \\
\text { Correlation }\end{array}$ & $\begin{array}{l}\text { Sig. (2- } \\
\text { tailed) }\end{array}$ & $\begin{array}{c}\text { Pearson } \\
\text { Correlation }\end{array}$ & $\begin{array}{c}\text { Sig. (2- } \\
\text { tailed) }\end{array}$ \\
\hline Time & 0.752 & 0 & -0.939 & 0 \\
\hline $\begin{array}{l}\text { Odd-Even } \\
\text { Period }\end{array}$ & -0.563 & 0 & -0.126 & 0.374 \\
\hline
\end{tabular}

TABLE XIII. CORRELATION OF VOLUME IN SEGMENT 2

\begin{tabular}{|l|l|l|l|l|}
\hline \multirow{4}{*}{ Variable } & \multicolumn{4}{|c|}{ Correlation } \\
\cline { 2 - 5 } & \multicolumn{2}{|c|}{$\begin{array}{c}\text { Sudirman-Merdeka } \\
\text { Barat }\end{array}$} & \multicolumn{2}{c|}{$\begin{array}{c}\text { Merdeka Barat - } \\
\text { Sudirman }\end{array}$} \\
\cline { 2 - 5 } & $\begin{array}{c}\text { Pearson } \\
\text { Correlation }\end{array}$ & $\begin{array}{c}\text { Sig. (2- } \\
\text { tailed) }\end{array}$ & $\begin{array}{c}\text { Pearson } \\
\text { Correlation }\end{array}$ & $\begin{array}{c}\text { Sig. (2- } \\
\text { tailed) }\end{array}$ \\
\hline Time & 0.95 & 0 & -0.305 & 0.028 \\
\hline $\begin{array}{l}\text { Odd-Even } \\
\text { Period }\end{array}$ & -0.211 & 0.133 & -0.802 & 0 \\
\hline
\end{tabular}




\section{Busway Passenger Volume}

In this variable, the passenger volume being reviewed is the number of passengers of the Bus Rapid Transit (BRT), with a total of 13 corridors. The data was obtained from PT. Transportasi Jakarta, with the data being a detailed passenger statistic of March 2018 and December 2018, which is two months prior and after the expansion, respectively. The data was then processed, and the results are shown below on TABLE XIV.

TABLE XIV. AVERAge BRT PAssengers Before AND AFter the EXPANSION

\begin{tabular}{|l|l|l|l|}
\hline Odd-Even Period & \multicolumn{1}{|c|}{ Average } & Difference & Percentage \\
\cline { 1 - 2 } Before & 351535 & \multirow{2}{*}{23447} & 6.67 \\
\cline { 1 - 2 } After & 374982 & & \\
\hline
\end{tabular}

The table above shows an increase in monthly average users from before to after the expansion. The increase itself amounts to 23447 more users after the expansion, which is $6.67 \%$ of the initial number of passengers.

TABLE XV. CORRELATION BETWEEN BRT PASSENGER VOLUME AND RELATED VARIABLES IN MARCH AND DECEMBER 2018

\begin{tabular}{|l|l|l|}
\hline \multicolumn{3}{|c|}{ BRT Passenger Volume Correlation } \\
\hline \multicolumn{1}{|c|}{ Variable } & Pearson Correlation & Sig. (2-tailed) \\
\hline Date & -0.27 & 0.04 \\
\hline Period & 0.19 & 0.15 \\
\hline Day & -0.60 & 0.00 \\
\hline Working Day/Holiday & 0.90 & 0.00 \\
\hline
\end{tabular}

TABLE XV shows the results of data processing using SPSS. It can be seen from the table above that the Pearson Correlation coefficient for this variable is 0.19 , with a significance value of 0.15 . This low number of Pearson Correlation coefficient and significance value shows a Hypothesis Zero $(H O)$ relationship, which means that the odd-even period only weakly affects the BRT Passenger Volume.

More variables need to be considered to be able to correctly assess the cause of the increase in BRT passenger volume. The day and working day/holiday variables are then added. The table above shows a Pearson Correlation coefficient of -0.60 and 0.90 for the variables, respectively. This result shows that the two added variables are much more significant to the BRT passenger volume variable than the period variable, as the Pearson Correlation coefficient values tend to the Working Hypothesis $(H 1)$ rather than Hypothesis Zero $(\mathrm{H} 0)$. Moreover, during the expansion period, PT. Transportasi Jakarta also provides more active busses and better services, thus also being a factor affecting the increase of BRT passengers.

\section{CONCLUSIONS}

1) There is a $42.97 \%$ decrease of travel time from Period I to Period IV on both road segments reviewed, namely the Sudirman - Thamrin and the Kuningan St. segments.

2) With an increased coverage area of the regulation, there will be a reduction in travel time.

3) There is a $76.36 \%$ increase of average speed from Period I to Period IV on both road segments reviewed.
4) With an increased coverage area of the regulation, there will be an increase in average speed.

5) There is a $21.53 \%$ decrease of vehicle volume from Period II to Period III on the two road segments reviewed, namely the Sudirman St. and M.T. Haryono St. segments.

6) The data show the different relationship between the odd-even period and vehicle volume on the different road segments.

7) There is a $6.67 \%$ increase of monthly average BRT passenger volume from Period I to Period IV on all BRT corridors.

8) The correlation coefficient shows a weak interaction between the odd-even period variable and the BRT passenger volume variable, thus needing added variables, namely the day and working day/holiday variables.

\section{SugGeStions}

1) The DKI Jakarta Department of Transportation needs to conduct an extensive evaluation of the regulation, taking into account the growth rate of vehicles and the presence of LRT construction affecting several road segments.

2) More in-depth research needs to be conducted with more reviewed locations where the number of people shifting to BRTs is quantitatively assessed that aims to identify the effects that traffic engineering and restrictions have towards BRT passenger volume.

3) The DKI Jakarta provincial government needs to implement the odd-even regulation on a larger scale or other forms of restrictive regulation with automated surveillance.

\section{ACKNOWLEDGMENT}

We would like to give our highest appreciation for Indonesia University for providing an opportunity in studying the evaluation of odd-even policy implemented in Jakarta before and after the expansion of the rule. This study is funded through PITTA grant scheme No. ND162/UN2.R3.1/PPM.00/2019.

\section{REFERENCES}

[1] G. Eason, B. Noble, and I. N. Sneddon, "On certain integrals of

[2] Ferguson, E, Transportation Demand Management: Planning, Development, and Implementation. Michigan: American Planning Association, 2000.

[3] Tamin, Planning, Modelling, and Engineering Transportation (in Indonesian). Bandung: ITB, 2000.

[4] Mohan, D. T., Evaluation of Odd-Even Day Traffic Restriction Experiments in Delhi, India. New Delhi: Indian Institute of Technology Delhi, 2017

[5] Li, R. \& Guo, M. Effects of Odd-Even Traffic Restriction on Travel Speed and Traffic Volume: Evidence from Beijing Olympic Games, Beijing: Tsinghua University, 2016.

[6] Prayudyanto, M. N., Application Comparison of Travel Demand Management in Singapore and London (in Indonesian). Bandung: ITB, 2007.

[7] Direktorat Jenderal Bina Marga, Indonesian Road Capacity Manual (in Indonesian), Jakarta: Ministry of Public Works, 1997.

[8] Rodgers, J. L., Thirteen Ways to Look at the Correlation Coefficient. California: The American Statistician, 1988. 